\title{
Parametric Study for Replacement of Sand by Fly Ash for Better Packing and Internal Curing
}

\author{
Shirish V. Deo1, Arun D. Pofale ${ }^{2}$ \\ ${ }^{1}$ Civil Engineering Department, National Institute of Technology Raipur, Raipur, India \\ ${ }^{2}$ Civil Engineering Department, Visvesvaraya National Institute of Technology, Nagpur, India \\ Email: svdeo.ce@nitrr.ac.in, pophalearun@rediffmail.com
}

Received 20 February 2015; accepted 10 March 2015; published 12 March 2015

Copyright (C) 2015 by authors and Scientific Research Publishing Inc.

This work is licensed under the Creative Commons Attribution International License (CC BY). http://creativecommons.org/licenses/by/4.0/

(c) (i) Open Access

\section{Abstract}

The use of fly ash as replacement of sand is an economical solution for making green and denser concrete. The paper presents a concrete mix design procedure for partial replacement of sand with fly ash. Present method could produce additional compressive and flexural strength for concrete with partial replacement of sand with fly ash over control concrete, with higher slump. Addition of $0.5 \%$ super plasticizer could further improve compressive and flexural strength with higher slump over control concrete. Concrete with sand replaced by fly ash was also found to be economical without and with super plasticizer, when cost per $\mathrm{N} / \mathrm{mm}^{2}$ was compared. The beneficial effect may be attributed to better packing, pozzolanic activity of fly ash and internal curing by fly ash as partial replacement of sand. Based on experimental results, correlations are developed to predict compressive strength, flexural strength and cost per $\mathrm{N} / \mathrm{mm}^{2}$ for percentage sand replacement with fly ash.

\section{Keywords}

Fly Ash, Compressive Strength, Flexural Strength, Flow, Density, Internal Curing

\section{Introduction}

It is a pressing need today for the concrete industry to produce concrete with lower environmental impact, the so-called green concrete. This can be achieved in three ways. The first one is by reducing the quantity of cement as one tonne of cement saved will save equal amount of $\mathrm{CO}_{2}$ to be discharged into atmosphere. Secondly by reducing the use of natural aggregates whose resources are limited and are exhausting very fast. It is also achieved 
by utilizing maximum possible waste materials like fly ash in concrete. This will reduce the requirement of landfill area and make system more sustainable. The World Bank has reported that by 2015 disposal of fly ash will require 1000 square kilometre area or one square meter of land per person [1]. Also $\mathrm{SiO}_{2}$ and $\mathrm{Al}_{2} \mathrm{O}_{3}$ in fly ash react with the free lime available in concrete to form CSH and CAH gel. These gels provide extra cementing material and also fill the pores in concrete making it possible to reduce the quantity of cement.

Fly ash is generally used as replacement of cement, as an admixture in concrete, and in manufacturing of cement. Concrete containing fly ash as partial replacement of cement poses problems of delayed early strength development. Concrete containing fly ash as partial replacement of fine aggregate will have no delayed early strength development, but rather will enhance its workability and strength. This higher workability and strength achieved gives scope for indirectly reducing the cement quantity in concrete. Earlier investigations in respect of development of strength of cement mortars with fly ash showed the $50 \%$ to $80 \%$ increase in 91 days strength. For better packing of concrete more quantity of particle size less than 75 micron is highly desirable. This addition of finer particles will also increase the water requirement of the concrete mix. Addition of fly ash as replacement of sand fulfils this requirement of additional finer particles and improves workability and strength at same water content. Considering present scope of work only workability, cost and strength properties of concrete were studied. In future durability studies are recommended.

Fine aggregate occupies about $25 \%$ to $40 \%$ of total volume of concrete and hence provides great opportunity to utilize about $150 \mathrm{~kg}$ per $\mathrm{m}^{3}$ waste materials like fly ash for replacement. The need of fly ash utilization also arises out of the fact that good quality Natural River sand required in concrete and in the cement mortar, is depleting day by day and scarcity of good quality sand is felt by all metro and mega cities in India. Hence this study explores the possibility of replacing part of fine aggregate with fly ash by maximum density method and minimum voids method as a means of incorporating fly ash and reducing the consumption of natural sand. Both methods used in present study for replacing sand with fly ash are the oldest and basic conceptual methods and will provide a simple but effective way of replacing sand with fly ash at site.

Wang et al. [2] used recycled mineral admixture such as fly ash, slag, glass sand and rubber powder as replacement of $5 \%$ to $10 \%$ replacement of fine aggregate in their study of light weight concrete. With their study they reported that slump of the concrete with mineral admixtures was within design requirement. They also reported that light weight aggregate yielded better hardened properties than normal weight concrete and hence recommended higher use of waste resources in light weight green concrete for environmental protection.

Chatterjee [3] reported that about $50 \%$ of fly ash generated is utilised with present efforts. He also reported that, one may achieve up to $70 \%$ replacement of cement with fly ash when high strength cement and very high reactive fly ash is used along with the sulphonated naphthalene formaldehyde super plasticizer. He reported improvement in fly ash property could be achieved by grinding and getting particles in sub microcrystalline range.

Filho et al. [4] based on their study on high volume fly ash concrete with and without hydrated lime, they reported that, to maintain the same compressive strength of reference concrete at 91 days, concrete containing 50\% of fly ash must have reduced water to cemetatious ratio. More over they concluded that use of fly ash changed density and amount of calcium hydroxide in concrete were reduced.

Homnuttiwong [5] investigated compressive strength, water permeability and abrasion resistance of high volume fine fly ash and fine ground palm oil fuel ash concrete. They replaced up to $70 \%$ Portland cement type I by fine fly ash (FFA) and fine ground palm oil fuel ash (GPA). They reported that FFA was more reactive than GPA. Their results also confirmed that compressive strength, water permeability and abrasion resistance were comparable with normal concrete due to increase in pozzolanic activity of FFA.

Nambiar et al. [6] studied the influence of filler type on the properties of foam concrete. They reported the results of a systematic study to ascertain the influence of filler type (i.e. sand and fly ash) and the particle size of sand on the properties of moist cured foam concrete. Results showed that an increase in fly ash content results in higher strength for a given density, as fly ash is of pozzolanic nature.

Hwang et al. [7] based on their experimental results concerning the compressive strength development of concrete containing fly ash, the authors derived an estimation equation for compressive strength development taking into consideration age of concrete, fly ash content and Blain's specific surface area of fly ash. Based on the experimental results and from the developed equation authors concluded that the pores in concrete reduce by addition of fly ash as replacement of sand.

Arezoumandi et al. [8] Based on their study on 16 beams reported that normalised shear capacity of high volume fly ash concrete is higher than the cement concrete. 
Jones et al. [9] made an extensive laboratory based investigation into unprocessed low lime fly ash in foamed concrete as a replacement for sand. It is reported that the strength of fly ash concrete was more than 3 times higher than the sand concrete. More significantly, while the strength of sand mixes remained fairly constant beyond 28 days, those of fly ash foamed concrete at 56 and 180 days were up to 1.7 to 2.5 times higher than 28 days values, respectively.

Rebeiz et al. [10] reported investigation on the use of fly ash as replacement of sand in polymer concrete. The replacement of $15 \%$ sand with fly ash by weight increased the compressive strength by about $30 \%$. They also reported good surface finish due to addition of fly ash as replacement of sand which also reduces the permeability and has an attractive dark colour.

Siddique [11] carried out experimental investigation to evaluate the mechanical properties of concrete mixes in which fine aggregate (sand) was partially replaced with class F fly ash. Fine aggregate was replaced with $10 \%$, $20 \%, 30 \%, 40 \%$ and $50 \%$ of class $\mathrm{F}$ fly ash by weight. The test results showed that the compressive strength, splitting tensile strength, flexural strength and modulus of elasticity of fly ash concrete mixes with $10 \%$ to $50 \%$ fine aggregate replacement with fly ash showed improvement in the results as compared to control concrete. Replacement of fine aggregate with fly ash resulted in decreasing slump which needed more quantity of super plasticizers to be added to concrete.

Papadakis [12] used a typical low calcium fly ash as additive in mortar replacing, part of volume either of Portland cement or aggregate. In either case, $10 \%, 20 \%$ and 30\% addition to the cement weight was done. A very important finding was that when the compressive strength of mix in which aggregate was replaced by fly ash were similar to that of control mix at 3 and 14 days, but were higher from 28 days and later. The strength increase is due to higher content of calcium silicate hydrate (C-S-H; the main carrier of strength in hardened cement) due to reaction of $\mathrm{CH}$ produced from cement hydration with active silica of fly ash.

Freyne et al. [13], reported that high performance concrete mixtures with fly ash exhibited the best potential durability with crack densities less than $0.1 \mathrm{~m} / \mathrm{m}^{2}$.

Byard et al. [14] evaluated the effect of light weight fine aggregate on the cracking tendency of bridge deck using cracking frame testing technique. They reported that internal curing from light weight aggregate increased the time to initial cracking, reduced autogenous shrinkage stress development and increased the degree of hydration in bridge deck concrete.

Rukzon et al. [15] studied mortars with ternary blends of OPC, ground rice husk ash and classified fly ash. The mortar mixes were made by replacing OPC with $0 \%$ to $40 \%$ fly ash and rice husk ash with $1 \%$ to $3 \%$ by weight retained on sieve No. 325. Based on their results they reported that ternary blended cements of rice husk ash and fly ash produced mortar mixes with good strength and low porosity.

Castro et al. [16] studied effect of internal curing on low water cement ratio mortars. Based on the study they reported that with increase in internal curing level total absorbed water was reduced. Results also indicated that internal curing was beneficial from electrical conductivity point of view.

Famili et al. [17] studied effect of saturated light weight aggregate on material properties on concrete. They reported that shrinkage of sealed cured specimen containing light weight arrogate was lower than without light weight arrogate concrete.

From the literature reviewed it is clear that in India disposal of fly ash is a big problem. However as reported high volume fly ash concrete lowers compressive strength compared to cement concrete. In all referred literature replacement of sand with fly ash has produced higher strength than normal concrete with sand as fine aggregate. It is further observed that water absorbed by fly ash could also be used for internal curing of concrete, which may further reduce cracking.

\section{Experimental Programme}

\subsection{Materials}

Portland Pozzolana cement fly ash based was used. About 25\% cement is replaced with fly ash. It was tasted as per BIS 4031:1988. Properties are given in Table 1. Fly ash from fourth hopper (medium fine i.e. $<10 \%$ retained on 45 micron sieve) of thermal power plant at Khaperkheda, Nagpur, India was used in this investigation. It was tested as per BIS 1727:1967 and results are given in Table 2. Natural sand passing through 10 mm sieve was used as a fine aggregate. It was tested as per Indian Standard Specifications BIS: 383-1970. Sand was conforming to Zone II. Coarse aggregates passing $40 \mathrm{~mm}$ and $12.5 \mathrm{~mm}$ sieves were combined (60:40). The combined 
grading is as in Table 3. Synthetic polymer super plasticizer was used for present study.

Table 1. Properties of Portland Pozzolana cement fly ash based.

\begin{tabular}{ccc}
\hline S.N. & Property & Result \\
\hline 1 & Standard consistency & $24 \%$ \\
2 & Initial setting time & 130 minutes \\
3 & Final setting time & 200 minutes \\
4 & Fineness by sieving & $3.5 \%$ \\
5 & Soundness & $2 \mathrm{~mm}$ \\
& Compressive strength & $33.5 \mathrm{~N} / \mathrm{mm}^{2}$ \\
& 3 days & $41 \mathrm{~N} / \mathrm{mm}^{2}$ \\
\hline
\end{tabular}

Table 2. Properties of fly ash (medium fine from fourth hopper).

\begin{tabular}{|c|c|c|}
\hline \multicolumn{3}{|c|}{ PHYSICAL TESTS } \\
\hline \multirow{3}{*}{ Fineness } & Specific gravity & 2.227 \\
\hline & Retained on 45 micron sieve & $9 \%$ \\
\hline & Specific surface, blaine, $\mathrm{m}^{2} / \mathrm{kg}$ & 526 \\
\hline \multicolumn{3}{|c|}{ CHEMICAL ANALYSIS (\%) } \\
\hline & Silicon dioxide $\left(\mathrm{SiO}_{2}\right)$ & 55.5 \\
\hline & Aluminium oxide $\left(\mathrm{Al}_{2} \mathrm{O}_{3}\right)$ & 31.3 \\
\hline & Ferric oxide $\left(\mathrm{Fe}_{2} \mathrm{O}_{3}\right)$ & 6.4 \\
\hline & Calcium oxide (CaO) & 1.02 \\
\hline & Magnesium oxide (MgO) & 0.21 \\
\hline & Titanium oxide $\left(\mathrm{TiO}_{2}\right)$ & 2.7 \\
\hline & Sulphur trioxide $\left(\mathrm{SO}_{3}\right)$ & 0.44 \\
\hline & Loss on ignition & 0.74 \\
\hline
\end{tabular}

Table 3. Sieve analysis of all in aggregate.

\begin{tabular}{|c|c|c|c|c|c|}
\hline BIS sieve size & Sieves as per ASTM & $\begin{array}{c}\text { Sand } \\
\% \text { passing }\end{array}$ & $\begin{array}{c}\text { Coarse aggregate } \\
\% \text { passing }\end{array}$ & $\begin{array}{c}\text { Combined } \\
\text { grading \% passing }\end{array}$ & $\begin{array}{l}\text { Desirable grading } \\
\text { IS } 383 \% \text { passing }\end{array}$ \\
\hline $40 \mathrm{~mm}$ & $1.5 \mathrm{in.}$ & 100 & 100 & 100 & 100 \\
\hline $20 \mathrm{~mm}$ & 3/4 in. & 100 & 98 & 99 & $95-100$ \\
\hline $10 \mathrm{~mm}$ & 3/8 in. (9.5 mm) & 100 & 46 & 58 & ---- \\
\hline $4.75 \mathrm{~mm}$ & No.4 (4.45 mm) & 97 & 4 & 30 & $30-50$ \\
\hline $2.36 \mathrm{~mm}$ & No.8 (2.36 mm) & 92 & 0 & 26 & ---- \\
\hline $1.18 \mathrm{~mm}$ & No.16 (1.18 mm) & 83 & 0 & 24 & ---- \\
\hline $600 \mu$ & No.30 $(600 \mu \mathrm{m})$ & 50 & 0 & 14 & $10-35$ \\
\hline $300 \mu$ & No.50 $(300 \mu \mathrm{m})$ & 3 & 0 & 1 & ---- \\
\hline $150 \mu$ & No.100 $(150 \mu \mathrm{m})$ & 0 & 0 & 0 & \\
\hline
\end{tabular}




\subsection{Mix Proportions}

M45 concrete mix (control mix) was designed as per Indian Standard concrete mix design method (IS 10262: 1982) and its comparative performance was verified with respect to minimum voids method and maximum density method for partial replacement of sand with fly ash along with the addition of super plasticizer dose to enhance the workability and strength. For the designed mix five alternative cases were studied. C1 was a M45 control concrete mix as per BIS code method. C2 was a M45 concrete mix as per BIS code method with partial replacement of sand so that voids in sand are fully filled by fly ash (minimum voids method). For the given sand minimum voids in vibrated case were found to be $27 \%$ hence to fill those voids $27 \%$ of sand was replaced by fly ash. Sand was replaced by weight by fly ash considering additional fly ash volume will also occupy the voids between cement particles. C3 was a M45 concrete mix as per BIS code method with partial replacement of sand to achieve maximum density of sand and fly ash combined mix (maximum density method). For given sand fly ash mix vibrated bulk density was highest for $12 \%$ sand replacement by fly ash hence $12 \%$ sand was replaced by fly ash. In order to study the effect of super plasticizer on concrete $0.5 \%$ super plasticizer was added to C4 and C5. C4 was a M45 concrete mix as per BIS code method with partial replacement of sand by fly ash with minimum voids method along with $0.5 \%$ super plasticizer. C5 was a M45 concrete mix as per BIS code method with partial replacement of sand by fly ash with maximum density method along with $0.5 \%$ super plasticizer. Mix proportions are given in Table 4.

\subsection{Preparation, Casting and Testing of Specimens}

All the cubes and beams were vibrated on vibration table. After casting, all the test specimens were finished with a steel trowel. They were de molded after 24 hours and were put into a water-curing tank at standard temperature $27^{\circ} \mathrm{C} \pm 2{ }^{\circ} \mathrm{C}$. Numbers of specimens cast for each mix are given in Table 5. Experimental program was designed to understand the effect of partial replacement of sand with fly ash on important concrete properties like workability, strength and durability. To know effect of Workability slump cone and compacting factor were calculated. Compressive and flexural strength were investigated to study effect on strength which is needed for design of various structures. Long term performance of the structure depends on ability of concrete to resist weathering forces. This was checked by finding the ultrasonic pulse velocity.

\subsection{Fresh Concrete Properties}

Value of slump and compacting factor were found for fresh concrete. The results are presented in Table 4. Figure 1 shows a no slump concrete without fly ash as replacement of sand. Figure 2 shows $25 \mathrm{~mm}$ increase in

Table 4. Quantities for $1 \mathrm{~m}^{3}$ of compacted concrete and concrete properties.

\begin{tabular}{ccccccccccc}
\hline Mix & $\begin{array}{c}\text { W/C } \\
\text { ratio }\end{array}$ & $\begin{array}{c}\text { Cement } \\
(\mathrm{kg})\end{array}$ & $\begin{array}{c}\text { Sand } \\
(\mathrm{kg})\end{array}$ & $\begin{array}{c}\text { CA } \\
(\mathrm{kg})\end{array}$ & $\begin{array}{c}\text { FA } \\
(\mathrm{kg})\end{array}$ & $\begin{array}{c}\text { SP } \\
(\mathrm{kg})\end{array}$ & $\begin{array}{c}\text { Slump } \\
(\mathrm{mm})\end{array}$ & CF & $\begin{array}{c}\text { Density } \\
\left(\mathrm{kg} / \mathrm{m}^{3}\right)\end{array}$ & Remark \\
\hline C1 & 0.32 & 450 & 531 & 1319 & 0 & 0 & 0 & 0.71 & 2584 & Without fly ash \\
C2 & 0.32 & 450 & 388 & 1319 & 130 & 0 & 25 & 0.74 & 2482 & FA by MVM \\
C3 & 0.32 & 450 & 467 & 1319 & 58 & 0 & 15 & 0.73 & 2516 & FA by MDM \\
C4 & 0.32 & 450 & 388 & 1319 & 130 & 2.25 & 65 & 0.82 & 2507 & FA by MVM + SP \\
C5 & 0.32 & 450 & 467 & 1319 & 58 & 2.25 & 50 & 0.79 & 2544 & FA by MDM + SP \\
\hline
\end{tabular}

CA = Air Day Coarse Aggregate; FA = Fly Ash; Density = 24 Hr De Moulding Density; SP = Super Plasticizer; CF = Compacting Factor; MVM = Minimum Voids Method; MDM = Maximum Density Method.

Table 5. Specimens details.

\begin{tabular}{ccc}
\hline S.N. & Mould dimensions & Number of specimens \\
\hline 1 & $100 \mathrm{~mm}$ cubes & 21 \\
2 & $150 \mathrm{~mm}$ cubes & 06 \\
3 & $100 \mathrm{~mm} \times 100 \mathrm{~mm} \times 500 \mathrm{~mm}$ beam specimens & 06 \\
\hline
\end{tabular}




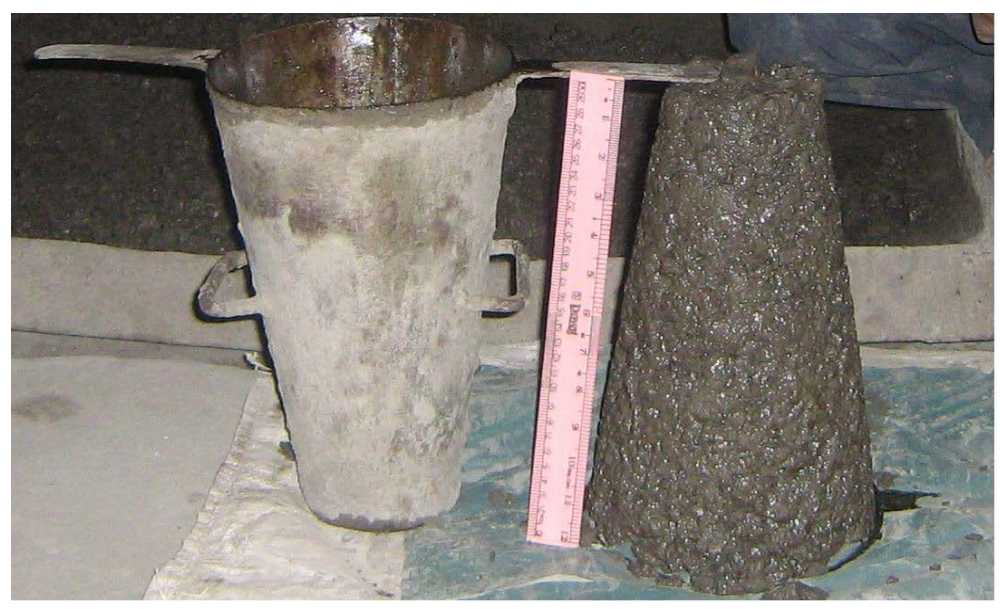

Figure 1. No slump concrete without fly ash.

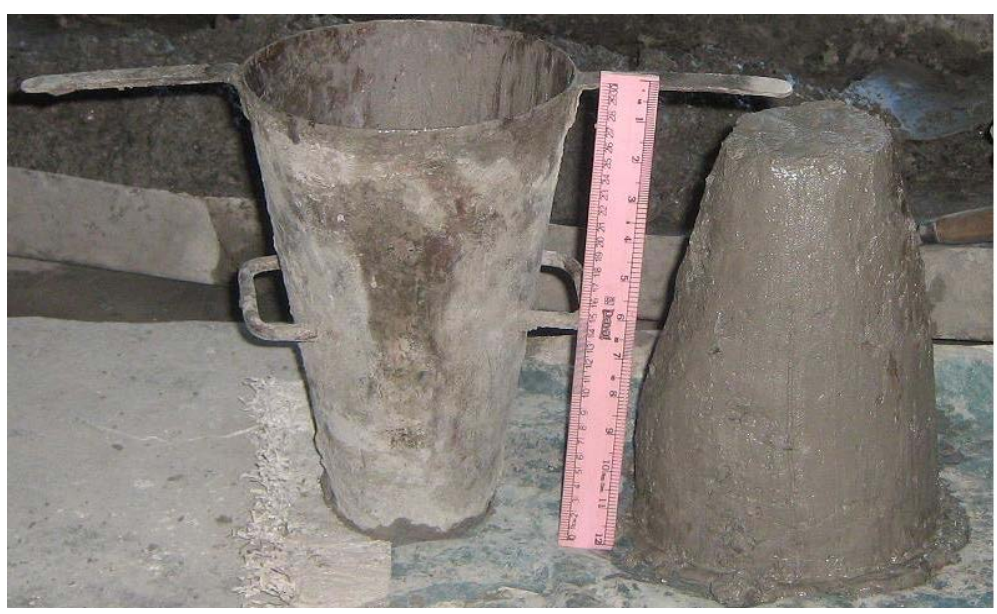

Figure 2. $25 \mathrm{~mm}$ slump concrete with $27 \%$ fly ash.

slump of concrete with $27 \%$ fly ash as replacement of sand.

\subsection{Compressive Strength and Flexural Strength of Concrete}

$150 \mathrm{~mm}$ cubes were tested on seventh and twenty eighth day. The results are given in Table 6. $100 \mathrm{~mm}$ cubes were used to compare their strength with $150 \mathrm{~mm}$ cubes and extend the study long term effect up to 147 days. 3 number $100 \mathrm{~mm}$ cubes each were tested on 3, 7, 28, 56, 91 and 119 days of curing. One set of 3 cubes in each mix was tested after 28 days of air curing to know the internal curing due to fly ash in concrete. Compressive strength results are shown Figure 3. $100 \times 100 \times 500 \mathrm{~mm}$ beams were tested on 7 and 28 days and results are given in Table 7.

\section{Results and Discussion}

\subsection{Compressive and Flexural Strength}

Compressive strength of $150 \mathrm{~mm}$ cubes at 7 and 28 days is given in Table 5 . Results reveal that for $12 \%$ and $27 \%$ replacement of sand with fly ash, compressive strength is always higher than the control concrete. Also results indicate positive effect of super plasticizer on strength of concrete. The compressive strength of $100 \mathrm{~mm}$ cubes at 3, 7, 28, 56, 91, 119 and 147 days is shown in Figure 3. Results indicate higher strength because of partial replacement of sand with fly ash even from 3rd day. This increase may be attributed to better packing of concrete ingredients due to lubricating effect of fly ash and reduction of voids due to finer fly ash particles fill 
Table 6. Compressive strength of $150 \mathrm{~mm}$ cubes.

\begin{tabular}{cccc}
\hline \multirow{2}{*}{ Mix } & Description & \multicolumn{2}{c}{${\text { Compressive strength in } \mathrm{N} / \mathrm{mm}^{2}}^{2}$} \\
\cline { 3 - 4 } C1 & Without fly ash & 7 days & 54.7 \\
C2 & FA by MVM & 38.7 & 63.1 \\
C3 & FA by MDM & 44.2 & 59.7 \\
C4 & FA by MVM + SP & 41.3 & 69.2 \\
C5 & FA by MDM + SP & 48.6 & 66.7 \\
\hline
\end{tabular}

FA = Fly Ash; SP = Super Plasticizer. Rounding off is done up to 1st place of decimal.

Table 7. Flexural strength of $100 \mathrm{~mm}$ beams and $100 \mathrm{~mm}$ cubes.

\begin{tabular}{|c|c|c|c|c|c|}
\hline \multirow{2}{*}{ Mix } & \multirow{2}{*}{ Description } & \multicolumn{2}{|c|}{$\begin{array}{l}\text { Flexural strength } \\
\text { in } \mathrm{N} / \mathrm{mm}^{2}\end{array}$} & \multicolumn{2}{|c|}{$\begin{array}{l}\text { Compressive strength } \\
\text { in } \mathrm{N} / \mathrm{mm}^{2}\end{array}$} \\
\hline & & 7 days & 28 days & 7 days & 28 days \\
\hline $\mathrm{C} 1$ & Without fly ash & 4.4 & 4.4 & 45.8 & 66.2 \\
\hline $\mathrm{C} 2$ & FA by MVM & 4.8 & 4.8 & 51.4 & 75.6 \\
\hline C3 & FA by MDM & 4.6 & 4.6 & 48.2 & 70.7 \\
\hline $\mathrm{C} 4$ & FA by $\mathrm{MVM}+\mathrm{SP}$ & 5.0 & 6.4 & 56.9 & 83.4 \\
\hline C5 & FA by $\mathrm{MDM}+\mathrm{SP}$ & 5.0 & 6.2 & 54.5 & 78.7 \\
\hline
\end{tabular}

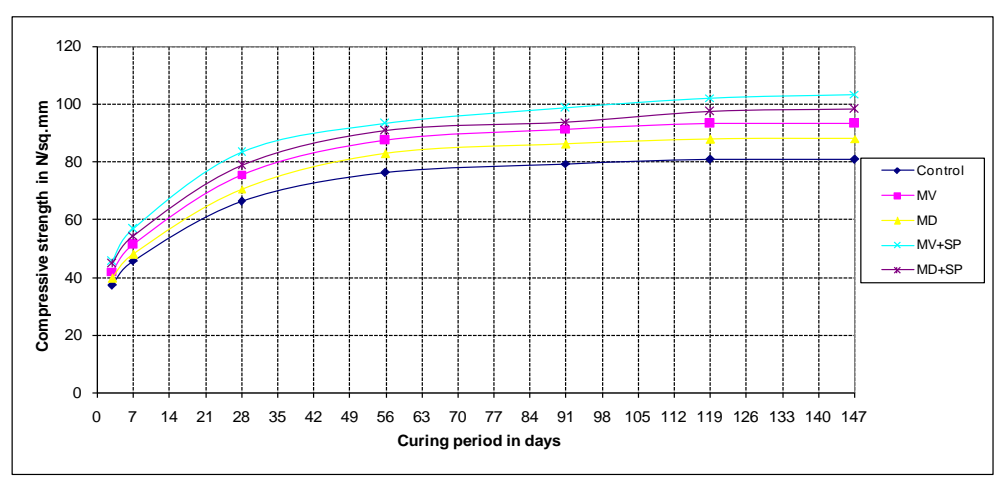

Figure 3. Variation of compressive strength with curing period in days for $100 \mathrm{~mm}$ cubes.

ing the voids between the cement particles. Better packing and voids filling was also confirmed by ultrasonic pulse velocity results. The compressive strength is increasing up to 147 days due to pozzolanic activity of the fly ash. The compressive strength with 28 days of air curing from 119 days to 147 had also increased. $100 \times 100 \times$ $500 \mathrm{~mm}$ beam results given in Table 6 also indicate higher flexural strength with replacement of the sand with the fly ash and addition of the super plasticizer. In all the cases the maximum strength is achieved with $27 \%$ sand replacement with the fly ash and the super plasticizer. Tables $\mathbf{8 - 1 0}$ indicate percentage increase in the strength over the control concrete by addition of the fly ash as replacement of the sand. On 7th day $14.3 \%$ and $25.7 \%$ increase in strength was observed over control concrete by replacement of sand with fly ash without and with super plasticiser. This increase is clearly due to reduction of voids or better packing of materials as pozzolanic action of fly ash starts after 7 days. $15.4 \%$ and $26.6 \%$ increase in compressive strength was achieved over control concrete with the partial replacement of the sand with the fly ash without and with the super plasticizer, respectively due to pozzolanic action and reduction of voids. Table 10 also indicates $9.1 \%$ and $13.6 \%$ increase in 7th day flexural strength over the control concrete with the partial replacement of the sand with the fly 
Table 8. Percentage increase in compressive strength of $150 \mathrm{~mm}$ cube by fly ash addition.

\begin{tabular}{cccc}
\hline Mix & Description & 7 days & 28 days \\
\hline C1 & Without fly ash & \multicolumn{2}{c}{ Control concrete } \\
C2 & FA by MVM & 14.3 & 15.4 \\
C3 & FA by MDM & 6.8 & 9.1 \\
C4 & FA by MVM + SP & 25.7 & 26.6 \\
C5 & FA by MDM + SP & 19.7 & 22.1 \\
\hline
\end{tabular}

Table 9. Percentage increase in compressive strength of $100 \mathrm{~mm}$ cube by fly ash addition.

\begin{tabular}{rcccccccc}
\hline Mix & Description & 3 days & 7 days & 28 days & 56 days & 91 days & 119 days & 147 days \\
\hline C1 & Without fly ash & & \multicolumn{7}{c}{ Control concrete } \\
C2 & FA by MVM & 13.26 & 12.15 & 14.25 & 14.88 & 15.13 & 15.41 & 15.61 \\
C3 & FA by MDM & 7.08 & 5.17 & 6.85 & 8.74 & 8.53 & 8.88 & 9.05 \\
C4 & FA by MVM + SP & 22.68 & 24.15 & 26.04 & 22.36 & 24.42 & 26.65 & 28.04 \\
C5 & FA by MDM + SP & 20.53 & 18.92 & 18.94 & 19.21 & 18.24 & 20.86 & 21.81 \\
\hline
\end{tabular}

Table 10. \% increase in flexural strength of $100 \mathrm{~mm}$ beam by fly ash addition.

\begin{tabular}{cccc}
\hline Mix & Description & 7 days & 28 days \\
C1 & Without fly ash & \multicolumn{2}{c}{ Control concrete } \\
C2 & FA by MVM & 9.1 & 11.1 \\
C3 & FA by MDM & 4.5 & 7.4 \\
C4 & FA by MVM + SP & 13.6 & 18.5 \\
C5 & FA by MDM + SP & 13.6 & 14.8 \\
\hline
\end{tabular}

ash without and with the super plasticizer, respectively. This increase is clearly due to reduction of voids or better packing of materials as pozzolanic action of fly ash starts after 7 days. Also about $11 \%$ and $18 \%$ increase in the flexural strength was achieved over the control concrete with the partial replacement of the sand with the fly ash without and with the super plasticizer, respectively due to pozzolanic action and reduction of voids. Table 11 shows the correlation between compressive strength of $150 \mathrm{~mm}$ and $100 \mathrm{~mm}$ compressive strength as percentage. Table 12 indicates correlation for $100 \mathrm{~mm}$ beam flexural strength and $100 \mathrm{~mm}$ cube compressive strength as percentage. Based on the experimental results correlations are developed for predicting compressive strength and flexural strength of concrete which are as given below from Equation (1) to (4) without super plasticizer

$$
\begin{array}{r}
f_{c k 119}=-90.864 x^{2}+70.57 x+80.67 \\
f_{t 28}=-7.4074 x^{2}+4.2222 x+5.4
\end{array}
$$

With super plasticizer

$$
\begin{gathered}
f_{c k 119}=-404.14 x^{2}+188.75 x+80.67 \\
f_{t 28}=-19.753 x^{2}+9.037 x+5.4
\end{gathered}
$$

The compliance of above equation is justified since they were found to have $R^{2}=1$.

Where $f_{c k 119}=$ compressive strength at 119 days; $f_{t 28}=$ flexural strength at 28 days; $x=$ percentage replacement of sand with fly ash. 
Table 11. Correlation for $150 \mathrm{~mm}$ and $100 \mathrm{~mm}$ compressive strength.

\begin{tabular}{cccc}
\hline & & \multicolumn{2}{c}{ Ratio of compressive strength \% } \\
$f_{\text {ck } 150 \mathrm{~mm}} / f_{\text {ck } 100 \mathrm{~mm}}$ & 28 days \\
\cline { 3 - 4 } Mix 1 & Description & 7 days & 82.6 \\
C2 & Without fly ash & 84.4 & 83.5 \\
C3 & FA by MVM & 86.0 & 84.4 \\
C4 & FA by MDM & 85.7 & 83.0 \\
C5 & FA by MVM + SP & 85.4 & 84.8 \\
\hline
\end{tabular}

Table 12. Correlation for $100 \mathrm{~mm}$ beam flexural strength and $100 \mathrm{~mm}$ cube compressive strength.

\begin{tabular}{cccc}
\hline \multirow{2}{*}{ Mix } & Description & \multicolumn{2}{c}{ Ratio of flexural strength to compressive strength in \% } \\
\cline { 2 - 4 } C1 & Without fly ash & 7 days & 28 days \\
C2 & FA by MVM & 9.6 & 8.2 \\
C3 & FA by MDM & 9.3 & 7.9 \\
C4 & FA by MVM + SP & 9.5 & 7.2 \\
C5 & FA by MDM + SP & 8.8 & 7.7 \\
\hline
\end{tabular}

\subsection{Workability}

The slump and compacting factor were determined for fresh concrete to understand effect on workability. The results are given in Table 4. It is evident from the result that slump and compaction factor increases with the partial replacement of the sand with the fly ash and addition of the super plasticizer. Addition of fly ash as replacement of sand has more pronounced lubricating effect and ball bearing action in the concrete. This concrete also has lesser voids hence more cement paste will be available for lubrication and hence concrete becomes more workable. This is also justified by the lower Surface Index Factor by Murdock [18]. Increase in the slump was about $25 \mathrm{~mm}$ and $65 \mathrm{~mm}$ over the control concrete with the partial replacement of the sand with the fly ash without and with the super plasticizer, respectively.

\subsection{Density}

Density for different concrete mixes was determined. The results are given in Table 4 . The results show a marginal decrease in density of concrete with replacement of sand with fly ash and addition of super plasticizer along with partial replacement of sand with fly ash respectively. This may be because of fly ash being lighter material than sand. But since sand with lower volume was replaced by weight by fly ash with higher volume better packing is achieved to accommodate higher volume in one cubic meter of concrete. This clearly indicates reduction of voids over the control concrete with the partial replacement of the sand with the fly ash without and with the super plasticizer. Further study to quantify the reduction of voids in concrete is recommended, since it was beyond scope of present research.

\subsection{Cost per $\mathrm{N} / \mathrm{mm}^{2}$ Strength}

To compare the cost effectiveness of the partial replacement of the sand with the fly ash cost per $\mathrm{N} / \mathrm{mm}^{2}$ strength is calculated. These values are given in Table 13. Decrease in the cost per $\mathrm{N} / \mathrm{mm}^{2}$ was about $15 \%$ and $22 \%$ over the control concrete with the partial replacement of the sand with the fly ash without and with the super plasticizer, respectively. This shows that partial replacement of sand with fly ash is economical over control concrete. Based on the experimental results correlations are developed for predicting 28 days and 119 days cost per $\mathrm{N} / \mathrm{mm}^{2}$ for concrete which are as given below from Equation (5) and Equation (6). 
Cost per $\mathrm{N} / \mathrm{mm}^{2}$ without super plasticizer

$$
\text { Cost }_{119}=117.28 x^{2}-72.407 x+71
$$

Cost per $\mathrm{N} / \mathrm{mm}^{2}$ with super plasticizer

$$
\text { Cost }_{119}=327.16 x^{2}-147.59 x+71
$$

$x=$ percentage replacement of sand with fly ash.

\subsection{Internal Curing by Fly Ash}

Fly ash used in present research work had water absorption of $16 \%$. Hence available fly ash in concrete as replacement of sand could supply about 20 liters of water for internal curing. This should result in better hydration product, pore structure etc. along with reduced internal cracking. To check possible internal curing with partial replacement of sand with fly ash $100 \mathrm{~mm}$ cubes were air cured for 28 days after 119 days of pond curing. The results as indicated in Table 14 show some improvement in the compressive strength of $100 \mathrm{~mm}$ cubes after 28 days of air curing. This additional strength after air curing must be due to internal curing effect of fly ash as replacement of sand. The internal curing by fly ash may result in formation of better hydration product. This reduces voids in concrete as could be seen with higher ultrasonic pulse velocity. Reduced voids also increase the strength of concrete.

\subsection{Ultrasonic Pulse Velocity}

Fly ash with its spherical nature and glass like nature acts like ball bearing to improve the packing of the concrete. This reduces the voids in concrete. To know the effect of partial sand replacement by fly ash ultrasonic pulse velocity of various concretes was tested and reported in Table 15. The results indicate improvement in the ultrasonic pulse velocity with partial replacement of sand with fly ash. Pulse velocity was found to be up to about $9 \%$ higher at 7 days. The higher pulse velocity at 7 days may be due to better workability of fly ash concrete over control concrete. The improvement of pulse velocity was also found up to 147 days. This improvement may be due to formation of additional CSH gel along with reduced voids. Additional CSH gel along with reduced voids in concrete with partial replacement of sand with fly ash should increase the durability of concrete

Table 13. Comparison of cost per $\mathrm{N} / \mathrm{mm}^{2}$.

\begin{tabular}{rcccc}
\hline & Description & Cost of concrete (Rs.) & $\begin{array}{c}\text { Cost per N/mm } \\
\text { at } 119 \text { days (Rs.) }\end{array}$ & $\begin{array}{c}\text { \% decrease in } \\
\text { cost per N/mm }\end{array}$ \\
\hline C1 & Without fly ash & 5710 & 71 & -- \\
C2 & FA by MVM & 5580 & 60 & 15.3 \\
C3 & FA by MDM & 5652 & 64 & 9.1 \\
C4 & FA by MVM + SP & 5625 & 55 & 22.2 \\
C5 & FA by MDM + SP & 5697 & 58 & 17.4 \\
\hline
\end{tabular}

Table 14. Effect of internal curing on compressive strength of $100 \mathrm{~mm}$ cubes.

\begin{tabular}{cccc}
\hline & & \multicolumn{2}{c}{ Compressive strength in N/mm $^{2}$} \\
Mix & Description & 119 days & 147 days \\
\cline { 3 - 4 } C1 & Without fly ash & 80.7 & 80.7 \\
C2 & FA by MVM & 93.1 & 93.3 \\
C3 & FA by MDM & 87.8 & 88.0 \\
C4 & FA by MVM + SP & 102.2 & 103.3 \\
C5 & FA by MDM + SP & 97.5 & 98.3 \\
\hline
\end{tabular}


Table 15. Ultrasonic pulse velocity of $100 \mathrm{~mm}$ cubes.

\begin{tabular}{cccccc}
\hline \multirow{2}{*}{ Mix } & Description & \multicolumn{2}{c}{ Ultrasonic pulse velocity m/sec } & \multicolumn{2}{c}{ \% Increase in ultrasonic pulse velocity } \\
\cline { 3 - 5 } & & 7 days & 147 days & 7 days & Control concrete \\
\hline C1 & Without fly ash & 2684 & 4198 & 5.44 & 18.89 \\
C2 & FA by MVM & 2830 & 4991 & 3.32 & 17.91 \\
C3 & FA by MDM & 2773 & 4950 & 8.83 & 26.04 \\
C4 & FA by MVM + SP & 2921 & 5291 & 7.49 & 22.15 \\
C5 & FA by MDM + SP & 2885 & 5128 & & \\
\hline
\end{tabular}

the scope of present study.

\section{Conclusions}

The following conclusions could be drawn from the present investigation.

1) Present mix design procedure clearly achieves lesser voids as indicated by higher pulse velocity, compressive and the flexural strength.

2) The compressive and the flexural strength of concrete mixes with partial replacement of sand by fly ash was found to be $15 \%$ higher without super plasticizer and $28 \%$ higher respectively with super plasticizer.

3) The compressive and the flexural strength of concrete mixes with the partial replacement of the sand by the fly ash by the minimum voids method could be higher than the replacement by the maximum density method. Hence the minimum voids method is preferable over the maximum density method for the partial replacement of the sand with the fly ash.

4) The maximum compressive and flexural strength could occur with the partial replacement of the sand with fly ash by the minimum voids method and the super plasticizer.

5) Slump was higher without and with super plasticizer in fly ash concrete over control concrete due to lubrication, ball bearing effect and better packing due to fly ash. This is also justified by lower Surface Index Factor by Murdock [18]. The higher slump and better packing has resulted in higher ultrasonic pulse velocity.

6) Density of concrete could decrease marginally though higher volume of material is packed in same volume by partial replacement of sand with fly ash. This reduction was higher for minimum voids method.

7) The cost per $\mathrm{N} / \mathrm{mm}^{2}$ was lower without and with super plasticizer making the partial replacement of the sand with the fly ash economical.

8) Internal curing effect of fly ash as partial replacement of sand may reduce cracks in concrete.

9) Proposed concrete is environmental friendly green concrete as it will save about $150 \mathrm{~kg}$ per $\mathrm{m}^{3}$ scarcely available natural sand and utilize equal amount of fly ash per cubic meter of concrete.

10) The concept of replacement of natural fine aggregate by fly ash highlighted in the present investigation could be taken into consideration during mix design of the pumpable concrete with high workability which generally demands more fine aggregates for smooth and uninterrupted flow of the mix.

11) It could be finally concluded that fly ash could be very conveniently used as partial replacement of sand in structural concrete where its proportion and replacement of sand could be efficiently done by using minimum voids method for higher compressive strength, flexural strength and workability and lower voids at lower cost.

\section{References}

[1] (2005) High Volume Fly Ash Concrete Technology Handbook. 3rd Edition.

[2] Wang, H.Y., Hsiao, D.H. and Wang, S.Y. (2012) Properties of Recycled Green Building Materials Applied in Light Weight Aggregate Concrete. Computers and Concrete, 10, 95. http://dx.doi.org/10.12989/cac.2012.10.2.095

[3] Chatterjee, A.K. (2011) Indian Fly Ashes: Their Characteristics and Potential for Mechanochemical Acivation for Enhanced Usability. Journal of Materials in Civil Engineering, 23, 783-788. http://dx.doi.org/10.1061/(ASCE)MT.1943-5533.0000279

[4] Filho, J.H., Medeiros, M.H.F., Pereir, E., Helene, P. and Isaia, G.C. (2013) High Volume Fly Ash Concrete with and 
without Hydrated Lime: Chloride Diffusion Coefficient from Accelerated Test. Journal of Materials in Civil Engineering, 25, 411-418. http://dx.doi.org/10.1061/(ASCE)MT.1943-5533.0000596

[5] Homnuttiwong, S., Jaturapitakkul, C. and Chindaprasirt, P. (2012) Permeability and Abrasion Resistance of Concrete Containing High Volume Fine Fly Ash and Palm Oil Fuel Ash. Computers and Concrete, 10, 349-360. http://dx.doi.org/10.12989/cac.2012.10.4.349

[6] Nambiar, E.K.K. and Ramamurthy, K. (2006) Influence of Filler Type on the Properties of Foam Concrete. Cement and Concrete Composites, 28, 475-480. http://dx.doi.org/10.1016/j.cemconcomp.2005.12.001

[7] Hwang, K., Noguchi, T. and Tomosawa, F. (2004) Prediction Model of Compressive Strength Development of Fly Ash Concrete. Cement and Concrete Research, 34, 2269-2276. http://dx.doi.org/10.1016/j.cemconres.2004.04.009

[8] Arezoumandi, M., Volz, J.S. and Myers, J.J. (2012) Shear Behaviour of High Volume Fly Ash Concrete versus Conventional Concrete. Journal of Materials in Civil Engineering, 25, 1506-1513. http://dx.doi.org/10.1061/(ASCE)MT.1943-5533.0000700

[9] Jones, M.R. and McCarthy, A. (2005) Utilizing Unprocessed Low Lime Coal Fly Ash in Foamed Concrete. Fuel, 84, 1398-1409. http://dx.doi.org/10.1016/j.fuel.2004.09.030

[10] Rebeiz, K.S., Serhal, S.P. and Craft, A.P. (2004) Properties of Polymer Concrete Using Fly Ash. Journal of Materials Engineering, 16, 15-19.

[11] Siddique, R. (2003) Effect of Fine Aggregate Replacement with Class F Fly Ash on Mechanical Properties of Concrete. Cement and Concrete Research, 33, 539-547. http://dx.doi.org/10.1016/S0008-8846(02)01000-1

[12] Papadakis, V.G. (1999) Effect of Fly Ash on Portland Cement Systems Part-I: Low Calcium Fly Ash. Cement and Concrete Research, 29, 1727-1736. http://dx.doi.org/10.1016/S0008-8846(99)00153-2

[13] Freyne, S., Ramseyer, C. and Giebler, J. (2012) High Performance Concrete Designed to Enhance Durability of Bridge Decks: An Oklahoma Experience. Journal of Materials in Civil Engineering, 24, 933-936. http://dx.doi.org/10.1061/(ASCE)MT.1943-5533.0000457

[14] Byard, B., Schindler, A.K. and Barnes, R.W. (2012) Early Age Cracking Tendency and Ultimate Degree of Hydration of Internally Cured Concrete. Journal of Materials in Civil Engineering, 24, 1025-1033. http://dx.doi.org/10.1061/(ASCE)MT.1943-5533.0000469

[15] Rukzon, S. and Chindaprasirt, P. (2008) Mathematical Model of Strength and Porosity of Ternary Blend Portland, Rice Husk Ash and Fly Ash Cement Mortar. Computers and Concrete, 5, 1-6.

[16] Castro, J., Spragg, R. and Weiss, J. (2011) Water Absorption and Electrical Conductivity for Internally Cured Mortars with W/C between 0.3 and 0.45. Journal of Materials in Civil Engineering, 24, 223-231.

[17] Famili, H., Saryazdi, M.K. and Parnizkar, T. (2012) Internal Curing of High Strength Self Consolidating Concrete by Saturated Light Weight Aggregate-Effect on Material Properties. International Journal of Civil Engineering, 10, 210-221.

[18] Murdock, L.J. (1960) The Workability of Concrete. Magazine of Concrete Research, 12, 135-144. http://dx.doi.org/10.1680/macr.1960.12.36.135 


\section{Recommendations}

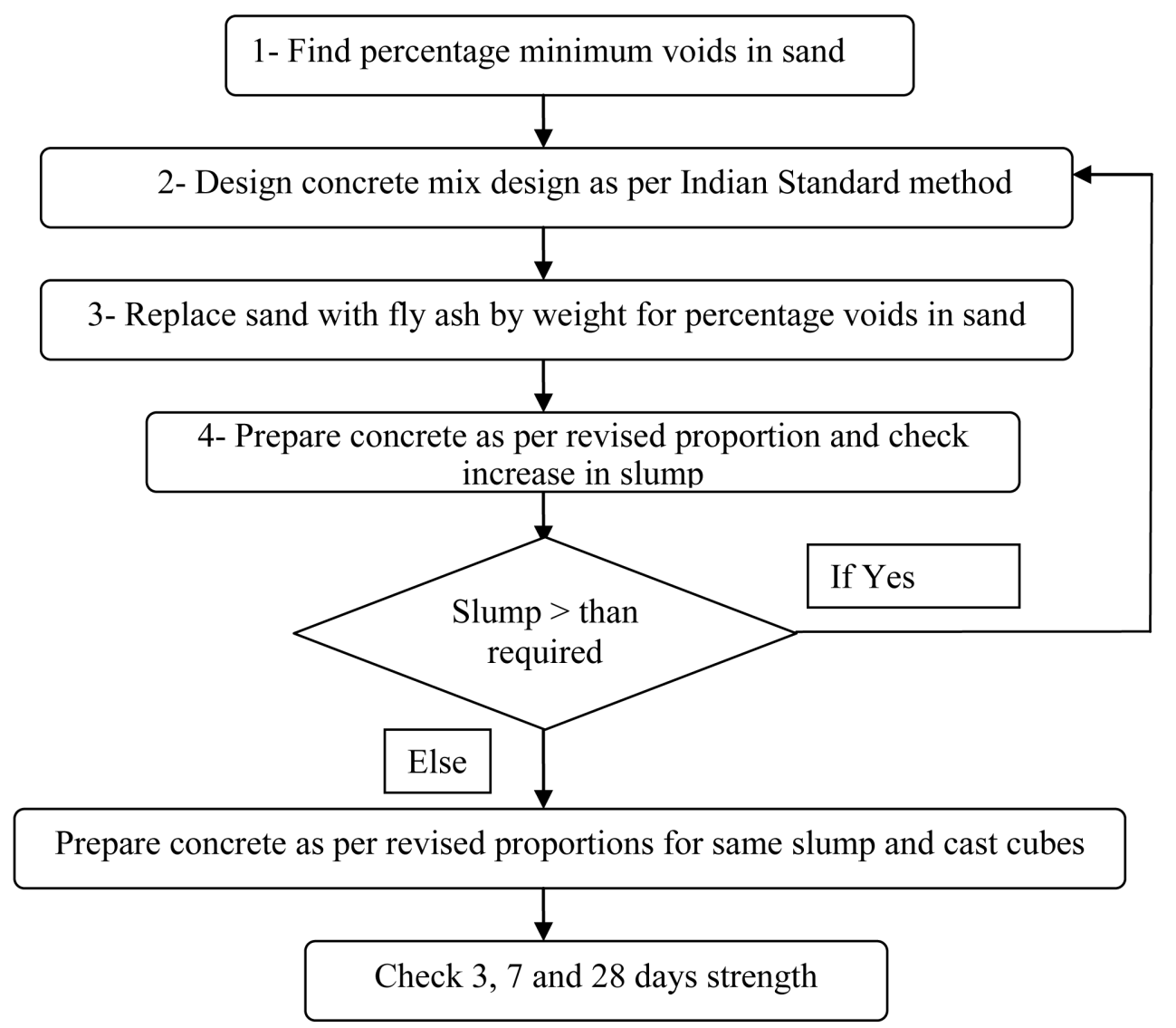

